\title{
Granice we wspinaniu. Góry jako przestrzenie transgresji granic płci
}

\author{
DOI: $10.19195 / 2084-4107.11 .24$
}

Góry i przestrzenie alpejskie wyznaczają nie tylko granice w sensie geograficznym czy topograficznym. Należy je rozumieć również jako przestrzenie socjalne, w nawiązaniu do dyskusji Spatial Turns, podlegające tworzeniu sieci powiązań i rozwijane na bazie społecznych powiązań. Te społeczne struktury prowadzą do konfigurowania odgraniczeń oraz konstruowania przestrzeni wewnętrznej i zewnętrznej ${ }^{1}$. W centrum dalszych rozważań będzie kwestia porządku płci w przestrzeni społecznej, jaką są góry. Zostanie ona ukazana na konkretnym przykładzie — historii wypraw wspinaczkowych w najwyższe góry świata, Himalaje. Ośmiotysięczniki „,Dachu Świata” mogą być traktowane jako historyczne miejsca, w których rozstrzygały i rozstrzygają się narodowe, sportowe, ekonomiczne a także kulturowe normy i praktyki. W tym kontekście spojrzymy z perspektywy historii płci na tak zwane wyprawy kobiece, czyli wyprawy górskie, które od połowy lat pięćdziesiątych były inicjowane, organizowane i przeprowadzane przez kobiety. Posłużą one jako soczewka analityczna pozwalająca przyjrzeć się stosunkom pomiędzy płciami i ich przemianom w przestrzeni społecznej wspinaczki wysokogórskiej. Postawimy przy tym pytanie o przekraczanie granic oraz o przywoływanie skonstruowanych społecznie norm odnoszących się do płci, względnie o strategie przezwyciężania tych norm.

\section{Granice płci w alpinizmie}

Przed rokiem 1950 kobiety tylko w nielicznych przypadkach - wyjątkowo nie towarzysząc swoim mężom — brały udział w wyprawach górskich w rejony himalajskie. Dopiero od tak zwanego „złotego wieku wypraw himalajskich”, jak chętnie określa się w historii alpinizmu etap od 1950 do 1965 r., alpinistki rozpoczęły podejmowanie samodzielnych wypraw ${ }^{2}$.

W europejskich Alpach już w latach dwudziestych XX w. spotykano wywołujące sensację „damskie zespoły”, a więc kobiety wspinające się bez towarzystwa mężczyzn. Jednak aż do lat sześćdziesiątych alpinistki, które wyznaczały sobie ambitne i trudne cele, postrzegane były ze sceptycyzmem i uprzedzeniami.

${ }^{1}$ Por. dyskusję dotyczącą przestrzeni w naukach społecznych, m.in.: Raumtheorie. Grundlagentexte aus Philosophie und Kulturwissenschaften, red. J. Dünne, S. Günzel, Frankfurt a. M. 2006; Spatial Turn. Das Raumparadigma in den Kultur- und Sozialwissenschaften, red. J. Döring, T. Thielmann, Bielefeld 2008.

2 Por. M. Isserman, S. Weaver, Fallen Giants. A History of Himalayan Mountaineering from the Age of Empire to the Age of Extremes, New Haven 2008, s. 254-294. 
Ekstremalne wspinaczki bez męskiego towarzystwa i przewodnictwa uchodziły za nieodpowiednie dla kobiet.

Nowoczesny alpinizm rozwijał się jako praktyka mieszczańskiego modernizmu od końca XVIII w., a w wiekach XIX i XX zaczęto przypisywać mu wartości imperialistyczne i nacjonalistyczne ${ }^{3}$. Ze względu na przebiegający w górach front w czasie I wojny światowej, który połączył postawę żołnierską z alpinizmem, ten ostatni został dodatkowo nacechowany męsko-militarnie 4 . „Zdobycie” znanych szczytów i dróg w Alpach oraz w Himalajach było do lat pięćdziesiątych ściśle związane z wyobrażeniami o obronie ojczyzny i o tożsamości narodowej ${ }^{5}$.

Inny aspekt, który spowodował, że alpinizm stał się fenomenem o przede wszystkim męskiej konotacji, to „usportowienie” wspinaczki w końcu XIX w. Jako działalność sportowa, która jest nieodłącznie związana z ryzykiem, niebezpieczeństwem i granicą pomiędzy życiem a śmiercią, wspinaczki górskie zyskały charakter „rytuału męskości” — jak określa to szwajcarska historyczka Tanja Wirz ${ }^{6}$. Wywodzący się z mieszczaństwa mężczyźni mogli w górach udowodnić swoją odwagę, siłę i zdecydowanie, a postać alpinisty awansowała do roli normatywnego konstruktu męskości ${ }^{7}$.

Wstęp na tę ,arenę męskości” kobiety miały tylko pod pewnymi warunkami. Dotyczyło to również publicystycznej dyskusji o alpinizmie. W ,alpejskiej literaturze służącej samookreśleniu", która od XIX w. była bardzo rozpowszechniona w Europie i Ameryce Północnej, dominowali męscy autorzy i bohaterskie przedstawienia ducha przygody, męskiego koleżeństwa i odwagi. Kobietom jeszcze w XX w. przyznawano w tych tekstach w najlepszym razie rolę potrzebujących pomocy i zatroskanych towarzyszek ${ }^{8}$.

Przez długi czas w historii alpinizmu kobiety były akceptowane w górach co najwyżej jako druga na linie lub na łatwiejszych drogach. Postawa związana z przekonaniem, że kobiety są fizycznie gorzej przystosowane do uprawiania alpinizmu, a nawet że ze względów charakterologicznych nie są w stanie go uprawiać, wynikała z dziewiętnastowiecznych mieszczańskich ideałów płci. Kobietom i mężczyznom były w tym porządku społecznym przypisywane od-

3 O związkach alpinizmu i modernizmu por. H.P. Hansen, The Summits of Modern Man. Mountaineering after the Enlightenment, Cambridge 2013.

${ }^{4}$ Dyskusja o poczuciu koleżeństwa w wojsku oraz połączeniu wojowniczej i alpinistycznej męskości poprzez I wojnę światową por. W. Backhaus, Bergkameraden. Soziale Nahbeziehungen im alpinistischen Diskurs (1860-2010), Frankfurt a. M.-New York 2016, s. 97-109.

5 Nanga Parbat była w latach trzydziestych i po II wojnie światowej stylizowana na „niemiecką górę przeznaczenia”, por. H. Höbusch, ,Mountain of Destiny”. Nanga Parbat and its Path into the German Imagination (Studies in German Literature, Linguistics and Culture), Rochester-New York 2016.

6 T. Wirz, Gipfelstürmerinnen. Eine Geschlechtergeschichte des Alpinismus in der Schweiz 1840-1940, Baden 2007, s. 146-147.

7 M.in. J. Rak, Social Climbing on Annapurna: Gender in High-altitude Mountaineering Narratives, „English Studies in Canada” 33, 2007, nr 1, s. $112 \mathrm{f}$.

${ }^{8}$ Por. D. Günther, Alpine-Quergänge. Kulturgeschichte des bürgerlichen Alpinismus (18701930), Frankfurt a. M.-New York 1998, 155-276. 
mienne zadania i role, zgodnie z którymi kobiety powinny jako żony i matki koncentrować się przede wszystkim na obowiązkach związanych ze sferą prywatną. Wiązało się z tym przekonanie, jakoby liczne aktywności sportowe były „niekobiece" i przynosiły kobietom szkodę fizyczną ${ }^{9}$. Wspinaczka winna być przez „panie” uprawiana z umiarem i powściągliwie. W poradnikach alpinistycznych przestrzegano kobiety przed nadmiernym wysiłkiem w górach, a to ze względu na niebezpieczeństwo „maskulinizacji” kobiecego ciała. Silne mięsnie i sprawne ciało (w rozumieniu sportowym) uchodziły za niestosowne dla kobiety wywodzącej się z mieszczaństwa ${ }^{10}$.

Kolejną granicę płci wyznaczyły organizacje alpinistyczne powstające w Europie, Ameryce Północnej, a także w Japonii i w Indiach w drugiej połowie XIX w. Proces ten zapoczątkował londyński Alpine Club uważający się za elitarną organizację wspinaczy. Do tego założonego w 1857 r. klubu nie dopuszczono kobiet $^{11}$. Alpinistki zostały również wykluczone w Szwajcarii ze Schweizer Alpinclub oraz z niektórych sekcji Niemieckiego i Austriackiego Związku Alpinistycznego ${ }^{12}$. W Wielkiej Brytanii i Szwajcarii wykluczenie kobiet ze związków doprowadziło do założenia związków alpinistycznych przeznaczonych wyłącznie dla kobiet, np. Ladies Alpine Club, Pinnacle Club czy też Schweizer FrauenAlpenclub. Związki te stworzyły fundament do tworzenia kobiecych zespołów wspinaczkowych i organizacji wypraw.

W dalszej części artykułu na przykładzie czterech przestrzeni społecznych i czasowych przedstawione zostaną granice i transgresje związane z wyprawami kobiecymi w latach 1955-2014.

\section{Poszerzenie przestrzeni działań: umiarkowane pionierki z Wielkiej Brytanii w latach 1955-1962}

Od początku XX w. europejskie wyprawy podejmowały ambitne próby zdobycia dolin i szczytów górskiego łańcucha Himalajów. Szczególnie intensywne stały się w latach dwudziestych starania zespołów brytyjskich o zdobycie Mount Everestu $(8848 \mathrm{~m})^{13}$. Od 1929 r. drugi pod względem wysokości szczyt Himalajów, Kanczendzonga (8586 m), a także leżący w pakistańskim Karakorum

9 Por. G. Pfister, „Auf den Leib geschrieben “-Körper, Sport und Geschlecht aus historischer Perspektive, [w:] Handbuch Sport und Geschlecht, red. I. Hartmann-Tews, B. Rulofs, Schorndorf 2006, s. 26-39; eadem, Hürdenlauf. Frauen erobern den Sport, „Ariadne” 69, 2016, s. 6-15.

10 Por. T. Wirz, op. cit., s. 310-315.

11 Por. C.A. Osborne, Gender and the Organisation of British Climbing 1857-1955, dysertacja, University of Lancaster 2004.

12 Por. T. Wirz, op. cit.; M. Achrainer, N. Mailänder, Der Verein, [w:] Berg heil! Alpenverein und Bergsteigen 1918-1945, red. Deutscher Alpenverein/Oesterreichischer Alpenverein/Alpenverein Südtirol, Wien-Köln 2011, s. 206.

13 Por. M. Isserman, S. Weaver, op. cit., s. 83-126. 
Nanga Parbat $(8126 \mathrm{~m})$ stały się celem wielu niemieckich ekspedycji ${ }^{14}$. Próby zdobycia ośmiotysięczników, w których do 1945 r. uczestniczyły również zespoły francuskie i amerykańskie, kosztowały życie wielu uczestników wypraw i nie przyniosły sukcesu do końca II wojny światowej.

Dopiero po ponownym otwarciu obszaru w 1950 r. zespołom wspinaczy różnych narodowości udało się do 1965 r. wspiąć na wszystkie ośmiotysięczniki. W 1953 r. zespołowi pod kierownictwem brytyjskim powiodło się zdobycie Mount Everestu. W oddziałującym mocno na opinię publiczną klimacie himalajskiej euforii, jaki wytworzył się w następstwie tego wydarzenia, w Szkocji wśród członkiń Ladies Scottish Climbing Club w 1954 r. również zaczął krystalizować się pomysł himalajskiej wyprawy górskiej do Nepalu. Scottish Women's Expedition w 1955 r. była pierwszą wyprawą zespołu czysto kobiecego mającą na celu pierwsze wejścia w Himalajach na góry powyżej $6000 \mathrm{~m}$.

Wybór zespołu kobiecego stanowił po II wojnie światowej dla brytyjskich alpinistek jedyną możliwość ucieczki przed alienacją w zespole męskim, a także jedyną możliwość samodzielnego zaplanowania i przeprowadzenia wyprawy. Jednakże aby tak się stało, trzeba było wielokrotnie pokonać społeczne (także związane z płcią) granice i przeszkody. $\mathrm{Z}$ jednej strony bariery ograniczające dostęp alpinistek brytyjskich do wspinania w Himalajach stawiały zdominowane przez mężczyzn instytucje, takie jak Alpine Club czy Royal Geographic Society. Obie te instytucje pełniły w odniesieniu do brytyjskich wypraw rolę gatekeepera i delegowały swoich członków do Himalayan Committee, gremium sprawdzającego planowane ekspedycje i umożliwiające im działalność poprzez zapewnienie wsparcia finansowego ${ }^{15}$. Ponadto instytucje te dysponowały ważną infrastrukturą, na przykład mapami oraz sprzętem, będącymi koniecznym warunkiem realizacji kosztownych wypraw w odległe góry.

Także granice dotyczące oczekiwań i obszarów działań związanych z płcią tworzyły silną przeszkodę dla himalaizmu lat pięćdziesiątych i sześćdziesiątych. Alpinistki musiały liczyć się z tym, że ze względu na negatywne uprzedzenia wobec zespołów kobiecych będą poddane szczególnie sceptycznej obserwacji opinii publicznej. Nawet wśród samych alpinistek pojawiały się opory i strach przed kompromitacją. Ladies Scottish Climbing Club, do którego należały trzy uczestniczki pierwszej kobiecej wyprawy w 1955 r., tak bardzo martwił się o swoją opinię wśród brytyjskich wspinaczy, że jego prezydium odmówiło zgody na używanie nazwy klubu w nazwie wyprawy. wywiadzie wpisującym się w metodę Oral-History-Interview dziewięćdziesięciodwuletnia Monica Jackson, kierowniczka tej wyprawy, wspomina:

14 Por. F. Torma, Auslandsbergfahrten, [w:] Berg heil!, s. 431-458; H. Höbusch, Ideologizing Nanga Parbat: High-Altitude Mountaineering and German Nationalism in the 1930s, „Sport in History" 23, 2003, nr 1, s. 64-88; P. Mierau, Nationalsozialistische Expeditionspolitik. Deutsche Asien-Expeditionen 1933-1945, München 2006.

15 Por. M. Jackson, E. Stark, Tents in the Clouds. The First Women's Himalayan Expedition, London 1956, s. 27. 
The funny thing was, we never met any man who said 'don't go'. But our own club didn't trust us. They didn't allow us to take the name of the club, because they thought we would bring dishonour on the club, but nobody else thought that. [...] We wanted to call it the 'Ladies Scottish Climbing Club Expedition' and they said 'No, you can't', so we called it the 'Scottish Women's Expedition'16.

W opublikowanej w 1956 r. relacji z wyprawy pod tytułem Tents in the Clouds Jackson wspomina - inaczej niż 57 lat później w wywiadzie będącym opowieścią o historii jej życia — bardzo wyraźnie „bad experiences”, jak streszcza przesądy dotyczące kobiecych ekspedycji, a także opory ze strony oficjalnych instytucji. Doświadczenia w planowaniu wyprawy przez kobiety opisywała w tamtym czasie jeszcze silniej jako ,ambiguous"17.

Tents in the Clouds od 1956 r. ukazało się w niemałych nakładach i zostało przetłumaczone na wiele języków ${ }^{18}$. Cała relacja z pierwszej kobiecej wyprawy może być traktowana jako próba obalenia panujących przesądów i wątpliwości. Demonstracja umiejętności zdobycia uznania w najwyższych górach, Himalajach, ukazywana jest przez trzy uczestniczki wyprawy na różnych płaszczyznach: perfekcyjnej organizacji, właściwego opanowania technik alpinistycznych i podejmowania przemyślanych i uzasadnionych decyzji, zbierania ważnych z naukowego punktu widzenia danych pomiarowych, a wreszcie dopasowanej do przyjętych form przedstawienia relacji z ekspedycji ${ }^{19}$.

Jak bardzo alpinistki jeszcze w XX w. internalizowały stereotypowe wyobrażenie o swojej drugorzędnej pozycji w alpinizmie, obrazuje poniższy cytat Joyce Dunshesth, organizatorki drugiej brytyjskiej wyprawy kobiecej (Abinger Himalayan Expedition) w 1956 r. W relacji wyprawowej Mountains and Memsahibs (opublikowanej w 1958 r.), z której pochodzi fragment, autorka opisuje swoje idealne wizerunki himalaistów oraz związane z nimi wątpliwości dotyczące spełnienia tych kryteriów przez siebie samą jako kobietę:

Many times in mylife I wished that I was a man of strong physique and outstanding climbing ability who would be an acceptable member of a Himalayan Expedition. [...] Himalayan Expeditions, I told myself, were only for men, and for that small percent age of men who have outstanding physical strength combined with that stead fastness of purpose

16 Wywiad z Monicą Jackson, 20.08.2013, Edinburgh.

17 Por. M. Jackson, E. Stark, op. cit., s. 13.

18 Niemieckie wydanie ukazało się w 2002 r.: M. Jackson, E. Stark, Zelteaufdem Dach der Welt. Die erste Frauen-Expedition in den Himalaya, München 2002.

19 Więcej o autoprezentacji alpinistek w Tents in the Clouds zob. M. Gugglberger, ,Mountain Femininity". Selbstpräsentationen und Legitimierungsstrategien im Rahmen der ersten HimalayaFrauenexpedition 1955, „Zeitgeschichte” 43, 2016, nr 1, s. 5-20. 
and determination which extends their powers and carries them even beyond the limits of human endurance ${ }^{20}$.

Z siedemnastu brytyjskich himalaistek, które wzięły udział w wyprawach kobiecych pomiędzy 1955 a 1962 r., dwanaście było mężatkami, ale tylko dwie matkami nieletnich dzieci. Wspomniana już Monica Jackson zostawiła swoje dzieci, które w czasie ekspedycji miały jedenaście i dwanaście lat, na trzy miesiące pod opieką znajomych i krewnych, którzy oprócz ojca troszczyli się o nie. Mimo to, jak wspomina, została wielokrotnie zwymyślana za takie postępowanie, otrzymywała też anonimowe listy, w których zarzucano jej zaniedbywanie roli matki. Wspominając to, wciąż samokrytycznie komentuje: „It was very selfish of me, but I went!"’21

Strategia, jaką przyjęły skonfrontowane z uprzedzeniami brytyjskie alpinistki lat pięćdziesiątych i sześćdziesiątych, polegała na ostrożnym i umiarkowanym przesuwaniu granic możliwości. Protagonistki tej generacji przed podjęciem wyprawy szukały wsparcia męskich mentorów i świadomie działały w miejscach niebędących celem ich męskich kolegów. Wybierały w Himalajach góry i tereny pomiędzy 6000 a $6500 \mathrm{~m}$ leżące z dala od wyścigu po ośmiotysięczniki. W tekstach publikowanych po zakończeniu wypraw wykorzystywały ponadto strategie legitymujące ich działalność w górach. Prezentowały się jako alpinistki o umiarkowanych ambicjach, wspinające się na średniowysokie, lecz dotąd niezdobyte szczyty, przeprowadzające przy tym pomiary i przygotowujące mapy.

Poza tym przedstawiały się świadomie jako kobiety konformistycznie pogodzone z tradycyjnymi rolami gospodyń domowych, żon i matek, wyznaczanymi własnej płci. W wielu miejscach relacji jest mowa o „domowym” zarządzaniu bazą, o praniu i pielęgnacji ciała. Okoliczność, że ideały piękna stoją w sprzeczności do surowego życia w górach, była kwitowana ironią. Uwidacznia to jednak po raz kolejny zasadnicze pogodzenie się z konwencjami kobiecości:

Shirts and underclothes hung to dry between the tents gave the camp a pleasantly domestic air (though male climbers might have shuddered at the array of feminine articles: some even had pink frills or were made of lace) and our unironed clothes were well in character with our sunburnt faces and matted hair. On rest-days we became comparatively elegant, had time to treat our complexions, cut our nails, and Eileen once washed her hair, an exotic sight against towering 20.000-ft. giants, but one which the Sherpas fully enjoyed ${ }^{22}$.

Pierwsza generacja himalaistek z Wielkiej Brytanii pod wieloma względami stąpała po nieznanym lądzie, przesuwając tym samym na stałe granice i przestrzenie możliwości dla zachodnich alpinistek w Himalajach. Po pierwszej Scottish

\footnotetext{
20 J. Dunsheath et al., Mountains and Memsahibs, London 1958, s. 1.

21 Wywiad z Monicą Jackson.

22 Dunsheath et al., Mountains and Memsahibs, S. 115.
} 
Women's Expedition w 1955 r. do 1962 r. miały miejsce kolejne cztery wyprawy kobiece wzorujące się na niej pod względem przygotowania i prezentacji przedsięwzięcia. Konsekwentne przedstawianie siebie jako umiarkowanych i skromnych, powtarzające się w dostępnych relacjach z wypraw, może być traktowane jako strategia poszerzania społecznych granic płci w sposób konformistyczny. Protagonistki dystansują się od jakiejkolwiek feministycznej krytyki społecznej, a wręcz umacniają stereotypy płci.

\section{Claude Kogan — alpinistyczne ambicje poza granicami płci}

Wyraźniej niż przedstawiona grupa brytyjskich zespołów kobiecych już pod koniec lat pięćdziesiątych wypowiadała się na temat ograniczonego dostępu kobiet do himalaizmu francuska alpinistka Claude Kogan. Była ona wyjątkową postacią w europejskim alpinizmie okresu powojennego. W latach 1951-1955 podejmowała liczne wyprawy w mieszanych pod względem płci zespołach w południowoamerykańskie Andy, w Kaukaz, a także w Himalaje ${ }^{23}$.

Claude Kogan przyszła na świat w Paryżu 21 lutego 1919 r. jako Claude Trouillet. Po rozwodzie rodziców, który nastąpił wkrótce po jej narodzinach, dorastała u matki w Brukseli, gdzie po ukończeniu nauki krawiectwa pracowała w branży tekstylnej. Ze wspinaniem zetknęła się w wieku osiemnastu lat poprzez krąg swoich belgijskich przyjaciół. W czasie II wojny światowej wyjechała z matką do Nicei znajdującej się wówczas pod okupacją włoską. Tam zatrudniła się w atelier krawieckim i szybko nawiązała kontakt z grupą alpinistów i alpinistek. Poprzez to środowisko poznała Jerzego Stefana Kogana, zwanego George'em, swego późniejszego męża. W kolejnych latach para podejmowała liczne przejścia górskie, również wspinaczkowe w Alpach. Kilka miesięcy po pierwszej wspólnej wyprawie górskiej do Peru George Kogan zmarł niespodziewanie w grudniu $1951 \mathrm{r}$. Obok działalności alpinistycznej w następnych latach Claude Kogan prowadziła od końca II wojny światowej w Nicei własne przedsiębiorstwo wytwarzające luksusową modę kąpielową ${ }^{24}$.

W 1954 r. alpinistka jako jedyna kobieta była członkiem zespołu ekspedycji himalajskiej pod kierunkiem szwajcarskiego wspinacza Raymonda Lamberta. W czasie próby zdobycia szóstego pod względem wysokości ośmiotysięcznika Cho Oyu (8201 m) Kogan osiągnęła wraz z Lambertem wysokość 7730 m zanim

${ }^{23}$ Pełna lista wypraw Kogan znajduje się w: E. Boutroy, Dernière de cordée. L'alpinism himalayen: les femmes à l'assaut d'un bastion de masculinité, [w:] Sport et genre, red. T. Terret et al., Paris 2005, s. 196.

${ }^{24}$ Por. C. Buffet, Première de cordée. Claude Kogan, femmed'audace et de passion, Paris 2003. Biografia autorstwa Buffeta jest jedynym całościowym przedstawieniem życia Kogan. Autor cytuje miejscami pamiętniki, artykuły prasowe i listy, jednakże nie podaje źródeł. Biografia jest utrzymana w stylu powieściowym

Góry, Literatura, Kultura 11, 2018

(C) for this edition by CNS 
próba wejścia musiała zostać przerwana ze względu na burzęę ${ }^{25}$ Kogan znana była potem we Francji jako „la femme la plus hautedumonde" 26 . Po powrocie powzięła plan zdobycia Cho Oyu w ramach wyprawy kobiecej.

W tym celu najpierw zebrała międzynarodowy zespół alpinistek. Jej motywacja polegała przede wszystkim na przejęciu kierownictwa wyprawy, a tym samym kompetencji decyzyjnej w górach. Pomimo jej bezdyskusyjnych umiejętności alpinistycznych było to niemożliwe w zespole męskim. W przeznaczonym prawdopodobnie dla sponsorów opisie koncepcji Expédition féminine au Cho Oyu kierowniczka wyprawy żądała równouprawnienia kobiet w dostępie do wspinaczek wysokogórskich w Himalajach, a warunki społeczne oraz role płci określała w sposób jednoznaczny jako przeszkody dla alpinistek:

Jusqu'à présent, ces expéditions extra-territoriales étaient surtout réservées aux hommes. Quelques rares femmes avaient eu le plaisier de pouvir (sic!) y participer et de découvrir les joies de l'exploration. Aussi était-il tout à fait normal que naisse parmi les femmes alpinistes, de quelque pays qu'elles soient, ce grand désir d'approcher les plus grandes montagnes du monde, c'est à dire la chaine de l'HIMALAYA [wyróżnienie w oryginale - M.G.]. [...] Les femmes en général, sont moins libres que les hommes; beaucoup d'entre elles ont des charges familiales qui les empêchent de s'absenter 3 mois ${ }^{27}$.

Francuska przedsiębiorczyni i alpinistka oprócz generalnego wyłączenia kobiet ze wspinania $\mathrm{w}$ górach wysokich wymieniała także inne ideały alpinistyczne stanowiące motywację dla wyprawy kobiecej: odkrycie i zbadanie nowych obszarów i przygodę, poszerzenie granic możliwości w alpinizmie. Podobnie jak jej brytyjskie poprzedniczki, mówiła o kobiecej „miłości do wspinania”, lecz wskazywała o wiele wyraźniej na granice płci we wspinaczce. Uwarunkowane społecznie obrazy ról zajmowanych w rodzinie i związane z tym zadania traktowała jako ograniczające mobilność i czasową elastyczność kobiet, utrudniające trwającą wiele miesięcy nieobecność. Tym niemniej Kogan żądała w swoim tekście dostępu kobiet do wypraw, również w góry najwyższe, a tym samym proklamowała w pewnym sensie równe szanse dla mężczyzn i kobiet we wspinaczce wysokogórskiej. Przyjmując tak prekursorskie stanowisko i wybierając za cel wyprawy ośmiotysięcznik, Claude Kogan zdecydowanie odżegnywała się od zasadniczej kobiecej skromności reprezentowanej przed nią przez brytyjskie pionierki.

25 C. Kogan, R. Lambert, Record à l'Himalaya, Paris 1963, s. 177-190.

${ }^{26}$ Przydomku tego używano w reklamach, artykułach prasowych, audycjach radiowych oraz w notatkach biograficznych, często ze wskazaniem na niewielki wzrost Claude Kogan; por. S. Jouty, H. Odier, Dictionnaire de la montagne, Paris 2009; C. Buffet, op. cit., s. 8, 167-172.

${ }^{27}$ C. Kogan, Détails sur l'organisation et les buts de l'expédition féminine à l'Himalaya 1959, typoskrypt opisu projektu z Files Eileen Healey, Alpine Club Archives, London, 1. 
Expédition féminine au Cho Oyu towarzyszyło duże zainteresowanie mediów. Claude Kogan w ramach finansowania przedsięwzięcia zawarła umowy na wyłączność z bulwarowymi gazetami „Paris Match” i „Daily Express”, do których dyspozycji uczestniczki musiały oddać zdjęcia i relacje.

Fakt, że wybór ośmiotysięcznika przekraczał stawiane himalaistkom w 1959 r. normatywne granice we wspinaczce uwidacznia się w ironicznych, a po części zjadliwych relacjach prasowych, które ukazywały się przed rozpoczęciem ekspedycji, ale przede wszystkim po jej zakończeniu. Wyprawa zakończona została po tragicznym wypadku lawinowym na wysokości ponad 7000 m, który kosztował życie kierowniczkę wyprawy Claude Kogan, Belgijkę Claudine van der Straten oraz dwóch Szerpów - Ang Norbu i Chewang. Wiadomość o tragedii na Cho Oyu szybko się rozprzestrzeniała — pomiędzy 18 października a 18 listopada 1959 r. gazety na całym świecie donosiły o tej „katastrofie” kobiecej wyprawy. W relacjach przebijał ton uwypuklający przekonanie, że pomimo niewątpliwych umiejętności wspinaczkowych kierowniczki wyprawy, szczyt ośmiotysięczny był zbyt wysoko ulokowanym celem, a także ton polemiki z ambicjami alpinistek nakierowanymi na sukces w ekstremalnych wspinaczkach. Przez artykuły prasowe przewijały się wizerunki i stanowiska związane ze społecznymi rolami oraz normatywne wyobrażenia dotyczące kobiecego ciała. „Daily Express” jedną z relacji dotyczących zakończenia wyprawy zatytułował „Women Obsessed!”28. Cechy charakteru, które w odniesieniu do wspinających się mężczyzn były traktowane jako służące w oczywisty sposób wybitnym osiągnięciom wspinaczkowym - siła woli, wytrzymałość i dążenie do celu, w odniesieniu do alpinistek były interpretowane jako obsesja i tępy upór. Alpinistkom zarzucano, że właściwym celem ich przedsięwzięcia była walka z mężczyznami, a wdzieranie się kobiet do sportu górskiego utożsamiano z zamachem na społeczny porządek płci.

Kobieca wyprawa Kogan była kamieniem milowym w historii kobiecego himalaizmu. Poprzez wybór jednego z czternastu najwyższych celów górskich na świecie alpinistki wyartykułowały ambicję do równouprawnionego dostępu do himalaizmu. Kobieca wyprawa na Cho Oyu przekroczyła tym samym związany z płcią teren działań na polu alpinizmu, który do tej pory wskazywał wspinającym się kobietom cele w Alpach lub też umiarkowane „góry świata”. Claude Kogan zapoczątkowała to, co stało się możliwe wśród wspinających się kobiet dopiero w latach siedemdziesiątych: otwarte występowanie jako ambitne alpinistki oraz wyrażanie krytyki wobec dyskryminacji i seksizmu odnoszącego się do kobiet w górach i w społeczeństwie. Innymi słowy, wykorzystanie przekroczenia granic w górach jako środka krytyki społecznej.

28 S. Harper, „Daily Express”, 26.10.1959. 
Kobiece wyprawy na tle ruchów kobiecych i krytyki dyskryminacji — lata siedemdziesiąte i osiemdziesiąte

W latach siedemdziesiątych i osiemdziesiątych sukcesywnie rosła liczba zespołów kobiecych próbujących sił w najwyższych górach. Zapoczątkowała to seria japońskich wypraw kobiecych, które doprowadziły w końcu do przekroczenia granicy 8000 m. W 1975 r. Japonka Junko Tabei (1939-2016) jako pierwsza kobieta zdobyła najwyższy szczyt ziemi, Mount Everest. Oprócz tego kierunki wytyczały w tym okresie amerykańskie i polskie wyprawy kobiece. Przede wszystkim amerykańska chemiczka Arlene Blum i polska inżynier elektronik Wanda Rutkiewicz zdominowały swymi tekstami i filmami dyskusje wokół kobiecego himalaizmu. Obie otwarcie mówiły o dyskryminacji i wykluczeniu alpinistek, a także krytykowały seksizm panujący w górach. Granice we wspinaniu, z którymi zetknęło się już pierwsze pokolenie himalaistek, funkcjonowały w niemal nienaruszony sposób także w tych dziesięcioleciach.

Arlene Blum opisywała w swojej opublikowanej w 1980 r. książce Annapurna: A Women's Place wykluczenia i wrogość, z którymi alpinistki musiały walczyć w USA jeszcze pod koniec lat siedemdziesiątych ${ }^{29}$. Ona sama wielokrotnie była wykluczana z wypraw, przy czym jako argument służyło stwierdzenie, jakoby kobiety wprowadzały niepokój w zespołach męskich. Na początku książki Blum cytuje broszurę reklamującą w połowie lat siedemdziesiątych wyprawę na Alaskę: „Women are invited to join the party at base and advanced base to assist in the cooking chores. Special rates are available. They will not beadmitted on theclimb, however" ${ }^{30}$. Otwarcie wyartykułowano tutaj, że pod pojęciem „wspinacza wysokogórskiego" rozumiani byli wyłącznie mężczyźni.

Jednak alpinistki w USA lat siedemdziesiątych musiały walczyć nie tylko z otwarcie wyrażanym wykluczeniem. Wyzwania związane ze sprawdzeniem się w górach były wielopłaszczyznowe i miały początek w samoświadomości alpinistek: „But as women, we faced a challenge even greaterthan the mountain. We had to believe in ourselves enough to make the attempt in spite of social convention and two hundred years of climbing history in which women were usually relegated to the sidelines" 31 .

Arlene Blum doszła do przekonania, że tylko zespół złożony z kobiet dałby możliwość osłabienia panujących uprzedzeń i udowodnienia, że alpinistki także są w stanie samodzielnie pokonać trudny szczyt. American Women`s Himalayan Expedition, którą kierowała w 1978 r., osiągnęła wreszcie sukces, zdobywając Annapurnę, ośmiotysięcznik uznany za niezwykle trudny i niebezpieczny.

29 A. Blum, Annapurna, A Woman's Place, San Francisco 1980; wydanie niemieckie: Annapurna. Die erste Frauenexpedition auf einen der höchsten Gipfel der Erde, Stuttgart 1982.

30 A. Blum, Breaking Trail. A Climbing Life, New York 2005, s. 47.

31 A. Blum, Annapurna..., s. 9 
W odróżnieniu od wychodzącego od stereotypów płci przypisywania winy w medialnych relacjach o wyprawie Claude Kogan z 1959 r., relacje dotyczące przedsięwzięcia Blum koncentrują się na przebiegu ekspedycji oraz generalnie na dotychczasowych osiągnięciach himalaistek. „New York Times” zatytułował swoją relację Himalayan Scaling Calledan Inspiration to Women, wysuwając na pierwszy plan symboliczny aspekt wydarzenia ${ }^{32}$. Zasadniczą wypowiedź, że wyprawa udowodniła umiejętności kobiet związane ze stawianiem sobie wysokich celów i osiąganiem ich, Blum umocniła swoją książką. Uchodzi ona za klasyczną i nowatorską pozycję literatury górskiej. Była to pierwsza relacja alpinistek, w której wypowiedziano się zdecydowanie politycznie, a do wspinania wysokogórskiego wprowadzono krytyczną feministyczną perspektywę. Gender stanowił dla Blum kategorię wiodącą, przy czym jednak nie zajmowała się innymi kategoriami, takimi jak orientacja seksualna czy pochodzenie etniczne. Jej tekst kierowany był do szerokiego kręgu czytelników i miał na celu obnażenie nierównego traktowania przy jednoczesnym przekazaniu na przykładzie American Women's Himalayan Expedition pozytywnego przykładu kobiecego przekraczania granic, uporu i zdecydowania.

Akceptacja dla kobiet w himalajskich zespołach wyprawowych była w latach siedemdziesiątych zróżnicowana i zależała od kontekstów kulturowych oraz narodowych. Podczas gdy w USA na porządku dziennym były seksistowsko motywowane wykluczenia alpinistek, w komunistycznej Polsce w ramach instytucji alpinistycznych powstała na przykład prężna grupa kobiet wspinających się w górach wysokich. W przeciwieństwie do American Alpine Club polski High Montain Club $^{33}$ wspierał i promował aktywności wyprawowe alpinistek wywodzących się z jego szeregów.

Polskie himalaistki utrzymywały w latach osiemdziesiątych — w odróżnieniu od wszystkich wcześniejszych ekspedycji kobiecych - purystyczny styl rozumiany zgodnie z surową definicją „truly feminine expeditions" ${ }^{34}$. Kryje się pod nią samodzielne działanie zespołów kobiecych w górach, bez wsparcia ze strony miejscowych pomocników płci męskiej, takich jak Szerpowie w Nepalu. Po części działo się tak z przyczyn pragmatycznych, gdyż polskie wyprawy ogólnie nie mogły sobie pozwolić na wynagrodzenia i utrzymanie dodatkowych miejscowych tragarzy.

Kluczową postacią polskiego himalaizmu stała się w latach osiemdziesiątych Wanda Rutkiewicz. Ta urodzona w 1942 r. inżynier elektrotechniki już w latach siedemdziesiątych zebrała doświadczenia w mieszanych pod względem

32 G. Lichtenstein, Himalayan Scaling Called an Inspiration to Women, „New York Times” 11.11.1978, s. 8.

33 Polski Związek Alpinizmu (przyp. tłum.).

34 Women's Expedition to K2. A challenge of $8611 \mathrm{~m}$, opis projektu, 1982, 3, zbiory prywatne Marion Feik, Wiedeń. 
płci zespołach wyprawowych, zaliczając wspinaczki w Pamirze i Hindukuszu ${ }^{35}$. W 1975 r. Rutkiewicz zorganizowała swoją pierwszą wyprawę do Pakistanu, w skład której wchodził zespół kobiecy i działający jednocześnie zespół męski. Ekspedycja została uwieńczona dużym sukcesem, przynosząc liczne pierwsze przejścia ${ }^{36}$ - Wanda Rutkiewicz wraz z brytyjsko-polską himalaistką Alison Chadwick-Onyszkiewicz znalazły się w zespole, który wszedł na Gaszerbrum III (7952 m) i zdobyły tym samym międzynarodowe uznanie. Umocniło się ono w 1978 r. po zdobyciu przez Rutkiewicz Mount Everestu jako pierwsza Europejka i trzecia kobieta świata.

W latach osiemdziesiątych polskie himalaistki zdominowały wyprawy kobiece w Himalaje. Tak na przykład w 1983 r. Krystynie Palmowskiej i Annie Czerwińskiej powiodło się zdobycie Broad Peaku $(8051 \mathrm{~m})$ w stylu alpejskim $\mathrm{w}$ jedynie trzy $\mathrm{dni}^{37}$. Wanda Rutkiewicz wykorzystywała swoje międzynarodowe kontakty z zachodnioeuropejskim środowiskiem alpinistek, realizując od $1982 \mathrm{r}$. w sumie siedem wypraw kobiecych.

Rutkiewicz w wielu tekstach i wywiadach zastanawiała się nad statusem kobiet we wspinaniu. Choć alpinistki uzyskiwały od lat sześćdziesiątych wsparcie polskich instytucji alpinistycznych, to sport ten również w Polsce pozostawał pod wpływem hegemonistycznie męskich wartości. Siła, odwaga, kondycja i wytrzymałość fizyczna, a także gotowość do podejmowania ryzyka należały, nie tylko w Polsce, wciąż do kanonu (męskiego) ideału wspinania ${ }^{38}$. Rutkiewicz odbierała otoczenie, w którym przyszło jej zbierać doświadczenia wspinaczkowe w Polsce, jako zdominowane przez mężczyzn. Konfrontowana była z podejściem, zgodnie z którym kobiety nie były traktowane jako równe partnerki w górach i we wspinaniu, tudzież z brakiem wiary samych kobiet we własne umiejętności. Wedle jej doświadczeń kobiety, które okazywały silne ambicje lub domagały się samodzielności, były natychmiast traktowane jako podające w wątpliwość istniejące $\mathrm{w}$ sporcie górskim porządek i hierarchię płci ${ }^{39}$. W związku z tym w publicznych wystąpieniach Rutkiewicz propagowała pogląd, że osiągnięcia alpinistyczne muszą być traktowane osobno dla każdej płci. W jej oczach tylko samodzielnie działający w górach zespół kobiecy mógł być faktycznie nazywany wyprawą kobiecą. Traktowała wyprawy jako szansę dla kobiet, aby w górach wysokich wspinać się samodzielnie i na własnych zasadach, a tym samym rozwijać swoje umiejętności:

35 M. Gugglberger, W. Rutkiewicz, Crossing Boundaries in Women's Mountaineering, ,Sport in Society" 2016, nr 1-18, w szczególności tabela 7.

36 Dwóm himalaistkom, Halinie Krüger-Syrokomskiej i Annie Okopińskiej, udało się wejście na Gaszerbrum II, a tym samym pierwsze kobiece wejście bez wsparcia męskiego na ośmiotysięcznik.

37 P. Nunn, Karakoram 1983, „Alpine Journal” 88, 1984, s. 212-213.

$38 \mathrm{~W}$ kwestii konstrukcji męskości we wspinaczce wysokogórskiej por. też S. Frohlick, The „Hypermasculine“ Landscape of High-altitude Mountaineering, „Michigan Feminist Studies” 14, 1999-2000, s. 83-106.

39 W. Rutkiewicz, B. Rusowicz, Wszystko o Wandzie Rutkiewicz, Toruń 1992, s. 44. 
It is essential for a woman to test her abilities in action and to learn to be independent on the mountain, apart from learning how to climb. [...] It does not mean that women, either individually or as a team, should not participate in men's expeditions or should not go with the help of [male - M.G.] Sherpas. [...] But women's ascent with men's expeditions should be listed after individual women's ascents ${ }^{40}$.

Rutkiewicz w swoim opublikowanym wykładzie wygłoszonym w ramach Himalayan Mountaineering and Tourism Meet w 1983 r. w New Delhi wyjaśniała, że we wspinaczce chodziło również o rywalizację sportową i, co nie bez znaczenia, o przesunięcie granic wyczynu. Fairness w kontekście porównywania osiągnięć widziała tylko w osobnym ocenianiu alpinistów i alpinistek. Sama przeżyła w czasie swojej wspinaczki na Mount Everest w 1978 r. poważne konflikty, gdy została oskarżona przez jednego z męskich partnerów wyprawowych, że jako kobieta jest traktowana w sposób uprzywilejowany, ponieważ niosła do bazy wysuniętej mniejszy ciężar. Zarzut ten kierowany był przede wszystkim przeciwko jej postulatom traktowania mężczyzn i kobiet w męskim zespole wyprawowym tak samo, pomimo różnic fizycznych. Jeden z kolegów zażądał, aby Rutkiewicz transportowała taki sam ciężar, aby móc faktycznie mówić o równości. Ze względu na te przeżycia himalaistka uważała podział wypraw ze względu na płeć za rozwiązanie dla „dylematu równości i różnicy”41.

Pod koniec lat osiemdziesiątych Rutkiewicz zmieniła swoją strategię, aby także pod ekonomiczną presją rynku związaną z rosnącą komercjalizacją wspinania w Himalajach — przeprowadzić swój projekt „Karawana do marzeń”. Tak jak pochodzący z Południowego Tyrolu himalaista Reinhold Messner oraz jej rodak Jerzy Kukuczka, postawiła sobie za cel zdobycie w rekordowym czasie wszystkich czternastu ośmiotysięczników; próba zakończyła się w 1992 r. zaginięciem Rutkiewicz na Kanczendzondze.

Himalaistki takie jak Arlene Blum i Wanda Rutkiewicz poszerzały w latach siedemdziesiątych i osiemdziesiątych granice przestrzeni działań kobiet we wspinaczce ekstremalnej, otwarcie piętnując dyskryminujące praktyki i seksizm. Nie tylko żądały oczywistego dostępu do wypraw w Himalaje, lecz w swoich tekstach, książkach i filmach potrafiły kreować swój wizerunek w sposób przynoszący sukces na alpinistycznym rynku autoprezentacji. Poza tym Rutkiewicz odniosła sukces w sportowej rywalizacji o rekordy i nowatorskie osiągnięcia w himalaizmie. Dzięki wielopłaszczyznowym transgresjom granic płci w górach Blum i Rutkiewicz na długo pozostały wzorcami dla późniejszych pokoleń alpinistek.

40 W. Rutkiewicz, Paper on Women's Mountaineering, [w:] Proceedings of the Himalayan Mountaineering and Tourism Meet 1983, New Delhi 1986, s. 135.

41 Por. S. Paletschek, Das Dilemma von Gleichheit und Differenz. Eine Auswahl neuerer Forschungen zur Frauengeschichte zwischen Aufklärung und Weimarer Republik, „Archiv für Sozialgeschichte" 33, 1993, s. 548-569; M. Minow, Making all the Difference. Inclusion, Exclusion and American Law, Ithac 1990. 


\section{Unity in Diversity — wyprawy kobiece jako polityczna strategia równouprawnienia}

Na zakończenie warto spojrzeć na sytuację w Nepalu — państwie leżącym w Himalajach, w którym w przeciągu ostatnich dwudziestu pięciu lat wyprawy kobiece również przesunęły granice w górach ${ }^{42}$. Branża turystyczna, która rozwijała się tu stopniowo od lat dwudziestych, a od lat sześćdziesiątych nabrała dynamiki, nigdy nie wykluczała całkowicie kobiet. Pojedyncze krewne były w obrębie rodzin Szerpów regularnie zatrudniane jako tragarze lub pomoce kuchenne $\mathrm{w}$ ramach ekspedycji ${ }^{43}$. Jednakowoż lepiej opłacana praca tragarzy wysokościowych oraz prowadzenie od lat osiemdziesiątych agencji trekkingowych były - i w większości są nadal — zarezerwowane dla mężczyzn. Nie mniej jednak w ostatnich latach postrzega się rozwijającą się branżę turystyki górskiej jako obszar oferujący kobietom możliwości kariery i rozwoju ${ }^{44}$. W związku z tym wiele programów wspierania kobiet stawia sobie za cel, po części w ramach współpracy międzynarodowej, celowe kształcenie przewodniczek trekkingowych i górskich ${ }^{45}$. Tego rodzaju przedsięwzięcia na rzecz równouprawnienia tworzyły w ciągu ostatnich piętnastu lat wielokrotnie ramy organizacyjne i finansowe dla wypraw kobiecych.

Inicjatywy pochodziły zarówno od pojedynczych osób, jak i od instytucji z obszaru turystki górskiej. W 2011 r. ogłoszonym „Nepal Tourism Year” nepalskie NGO Empowering Women of Nepal (EWN) zorganizowało Nepalese Women Annapurna IV Expedition mającą na celu wspieranie kobiet w branży trekkingowej i wyprawowej. Wyprawę poprzedził czteroletni program treningowy, którego celem było zapoznanie uczestniczek z technikami wspinaczki wysokogórskiej. Przy kompletowaniu zespołu wyprawowego decydującą rolę odgrywała różnorodność etniczna. Celowo do zespołu przyjęta została również uczestniczka z kasty tak zwanych „Dalits” (,Nietykalni”), dyskryminowanej w Nepalu grupy

42 Por. M. Gugglberger, Climbing Beyond the Summits: Social and Global Aspects of Women's Expeditions in the Himalayas, „The International Journal of the History of Sport” 32, 2015, nr 4, s. 597-613.

43 Por. S.B. Ortner, Life and Death on Mt. Everest. Sherpas and Himalayan Mountaineering, Princeton 1999, s. 217-247.

44 Ibidem, s. 155-172; K.C Sony, Analyzing the Roles and Challenges of Women in the Tourism Sector. An Ethnographic Study from Western Nepal, praca magisterska, Kathmandu University 2011.

45 Por. M.A. Jackson, Empowering Women of Nepal. An experience of empowerment in the land of the Himalaya, praca magisterska, Prescott College 2010. 
ludności ${ }^{46}$. Istotny czynnik wpływający na występowanie nierówności w Nepalu stanowi bowiem, obok różnorodności etnicznej, istniejący system kastowy ${ }^{47}$.

Tymczasowa konstytucja nowej demokracji z 2007 r. przewidywała federalną organizację państwa i proklamowała przede wszystkim trzy zasadnicze cele: równość, inkluzję i wspólnotę narodową ${ }^{48}$. W tym sensie kobiece ekspedycje w Nepalu służyły również jako przesłanie polityczne, jak dowodzi nazwa wyprawy First Inclusive Women Sagarmatha Expedition 2008. W projekcie współfinansowanym przez Nepalese Mountaineering Association zwracano uwagę na wybór uczestniczek z różnych obszarów etnicznych, religijnych i regionalnych. Świadome użycie nepalskiego określenia „Sagarmatha” zamiast ustanowionego w XIX w. przez Brytyjczyków „Mount Everest” było dodatkowym politycznym przesłaniem stawiającym w centrum uwagi dziedzictwo kulturowe i naturalne kraju. Po trwającej wiele lat wojnie domowej i zniesieniu monarchii w 2008 r. wyprawa miała demonstrować, w sposób oddziałujący na opinię społeczną, narodową tożsamość i samoświadomośćc ${ }^{9}$.

Zdobycie Mount Everestu (względnie Sagarmatha) wiąże się w Nepalu z wysokim prestiżem i oznacza dla himalaistek zwiększenie kapitału społecznego i symbolicznego w rozumieniu Pierre'a Bourdieu ${ }^{50}$. Nepalskim himalaistkom wyprawy kobiece otworzyły w konsekwencji poszerzone - po części transnacjonalne - przestrzenie działania, zwiększyły ich szanse na awans społeczny i ekonomiczną niezależność.

Międzynarodowe zainteresowanie budzi od 2014 r. trzyosobowy zespół, w skład którego wchodzą Maya Sherpa, Pasang Lhamu Sherpa Akita i Dawa Yangzum Sherpa. Wszystko z powodu wejść na drugi i trzeci pod względem wysokości szczyt Himalajów - K2 i Kanczendzongę. Pasang Lamu Sherpa Akita udało się po katastrofalnym trzęsieniu ziemi w Nepalu w 2015 r. wykorzystać międzynarodowe kontakty, przede wszystkim z USA, do uruchomienia licznych projektów pomocowych, w które sama angażowała się na miejscu. Za swoje charytatywne zaangażowanie oraz osiągnięcia w himalaizmie w czerwcu 2016 r. w Waszyngtonie została odznaczona, jako pierwsza Nepalka, National Geographic Explorer Award ${ }^{51}$.

${ }^{46}$ Pojęcie to określa należących do kast leżących poza czterostopniową hierarchią i uważanych za nieczystych; por. J. Gray, Caste and Ethnicity: Socio-Logics and Implications for a Federal States of Nepal, [w:] Ethnicity and Federalisation in Nepal, C. Mishra, O. Gurung, Kathmandu 2012, s. 124-138.

47 Por. ibidem, s. 124-138.

48 Por. ibidem, s. 133.

49 Historia demokratyzacji Nepalu do 2003 r. zob. J. Whelpton, A history of Nepal, CambridgeNew York 2005, szczególnie s. 208-235.

50 Por. P. Bourdieu, Ökonomisches, kulturelles und soziales Kapital, [w:] Soziale Ungleichheiten, red. R. Kreckel, Göttingen 1983, s. 183-199.

51 http://adventureblog.nationalgeographic.com/2016/02/04/pasang-lhamu-sherpa-akitaadventurer-of-the-year/ (dostęp: 9.08.2017). 
Kobiece wyprawy Nepalek wyraźnie różnią się od wspomnianych wcześniej górskich przedsięwzięć ze względu na warunki socjalne i ekonomiczne, lecz także w odniesieniu do ich znaczenia społeczno-politycznego. Służą one, obok celów alpinistycznych, przezwyciężeniu nie tylko granic płci, lecz przede wszystkim granic etnicznych i społecznych. Tym sposobem znaczenie kobiecych wypraw w Nepalu wykracza daleko poza współzawodnictwo sportowe. Działania himalaistek są ściśle związane z codziennymi i społeczno-politycznymi uwarunkowaniami kraju rozwijającego się, a wreszcie zależne od sieci wsparcia sięgających daleko poza granice kraju.

\section{Podsumowanie}

Społeczne porządki i hierarchie płci, tak jak stereotypowe wyobrażenia męskości i kobiecości, wyznaczały wspinającym się kobietom granice w kwestii ich partycypowania w himalaizmie. Motywacje i konteksty wypraw kobiecych zmieniały się w czasie minionych sześćdziesięciu lat. Ich wspólną cechę stanowi fakt, że z perspektywy historii płci można je traktować jako strategie przekraczania tych granic a poprzez to poszerzania obszarów działania kobiet w przestrzeni wysokogórskiej. 